\title{
KESALAHAN GRAMATIKA BAHASA ARAB PADA TULISAN MAHASISWA PRODI SASTRA ARAB UGM
}

\author{
Moh. Masrukhi \\ moh_masruhi@yahoo.com \\ Sastra Arab Departemen Bahasa dan Sastra \\ Fakultas Ilmu Budaya Universitas Gadjah Mada Yogyakarta
}

\begin{abstract}
Error in the language occurs due to speakers or learners already have rules of grammar different from other grammars being studied. An impact arises on the imperfection or inability of speakers implying the use of the language. This article will reveal the errors that arise as a result of the lack of dominance of the rules of the language being studied. The goal is to find out on what level the error occurred. This research data is taken from the final examination of the subjects of Arabic Text Review Semester I and Semester III students of Arabic. Further data is analyzed by utilizing existing Arabic structure concept or theory. The result is that these learners' language errors occur both on the lexicon, Arabic phrase and as well in Arabic clauses. From the results of this study can be argued that to avoid language errors, grammatical mastery or grammar of a second language requires a lot of practice, both written and oral.
\end{abstract}

Keywords: Learners, Error in the language, Arabic Grammar.

$$
\begin{aligned}
& \text { الخطأ في استخدام اللغة بسبب أن المتحدثين أو المتعلمين لديهم قواعد مختلفة عن القواعد الأخرى التي بتري فن }
\end{aligned}
$$

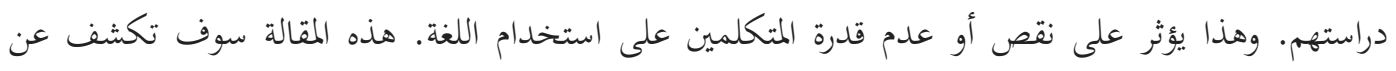

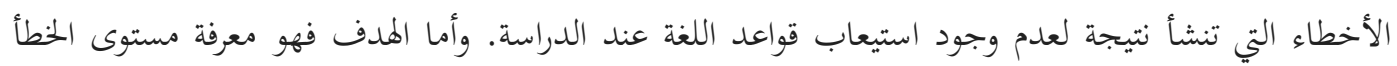

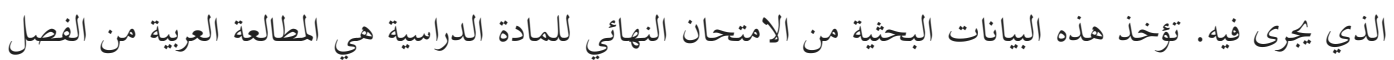

$$
\begin{aligned}
& \text { الأول و الفصل الثالث عند طلاب قسم اللغة العربية. يتم تحليل البيانات من خلال الاستفادة من مفهوم البنية }
\end{aligned}
$$

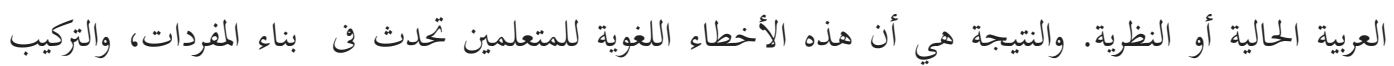

$$
\begin{aligned}
& \text { والجمل. ومن نتائج هذه الدراسة يمكن القول إن تجنب أخطاء استخدام اللغة من خلال إتقان القواعد للغة الثانية } \\
& \text { يتطلب منا كثيرا من الممارسات، سواء كان كتابة أم شفوية. } \\
& \text { الكلمات المفتاحية : المتعلم ، العلامة ، الخطأ اللغوي ، القواعد العربية . }
\end{aligned}
$$

\section{PENDAHULUAN}

Linguistik kontrastif menurut Wilkins (1972) dalam Pateda (1989:17) adalah adanya asumsi bahwa bahasa ibu mempengaruhi anak didik ketika mempelajari bahasa kedua. Penerapan teori-teori linguistik dalam pengajaran itulah kadang mengalami distorsi sehingga hasil yang diperoleh tidak sesuai dengan kaidah yang ada dan menimbulkan kesalahan. Di situlah analisis kontrastif menurut Buren (dalam Allen dan Corder, 1974:280) dapat dimanfaatkan. Ia mengatakan bahwa 
metode perbandingan yang digunakan dalam linguistik kontrastif adalah membandingkan unsur kebahasaan yangberbeda dan yang sama. Namun, dia menambahkan tekānannya lebih diarahkan kepada unsur kebahasaan yang berbeda.

Linguistik kontrastif memunculkan analisis kontrastif. Analisis kontrastif bermula dari anggapan perlunya memahami kebudayaan pemakai bahasa yang sedang dipelajari dan membandingkannya dengan budaya bahasa ibu. Hal ini perlu dilakukan karena bahasa merupakan media kebudayaan. Upaya membandingkan budaya si pembelajar dengan budaya asing tersebut diharapkan akan memperoleh gambaran yang seringkali menyebabkan timbulnya kesalahan. Dari kesalahan-kesalahan yang terjadi itulah si pembelajar dapat segera memahami dan menguasai bahasa yang bukan bahasa ibunya itu atau bahasa yang sedang dipelajari.

Analisis kesalahan berbahasa error analysis, dirintis oleh Pit Corder pada 1960-an, adalah kajian jenis dan penyebab kesalahan berbahasa. terutama dalam pemerolehan bahasa kedua, seperti pemerolehan bahasa Arab. Error adalah kesalahan berbahasa akibat penutur melanggar kaidah atau aturan tata bahasa (breaches of code).

Bahasa Arab merupakan bahasa kedua atau ketiga bagi orang Indonesia, termasuk pembelajar yang sedang belajar di perguruan tinggi, seperti Universitas Gadjah Mada. Pemerolehan bahasa ini menimbulkan pengetahuan baru bagi pembelajar terhadap kaidah-kaidah atau gramatika bahasa Arab. Pemerolehan kaidah-kaidah bahasa Arab ini berbedabeda, khususnya bagi pembelajar. Ada yang masih minim, terutama pembelajar yang berasal dari sekolah umum dan ada pula yang sudah mendapatkannya dari Madrasah Aliyah atau yang sederajat.

Penguasaan terhadap kaidah-kaidah atau gramatika bahasa kedua (Arab) belum seluruhnya terinternalisasi atau dikuasai pembelajar. Hal inilah yang kemudian mengakibatkan terjadinya kesalahan-kesalahan dalam berbahasa oleh mahasiswa dalam menulis atau membaca teks-teks bahasa Arab yang dihadapi. Kesalahan yang muncul pada tulisan mahasiswa tersebut dapat dicontohkan seperti pada kalimat berikut:

$$
\text { "أخذ ما أحب ولكن لا أستطيع أن أعملهِ" }
$$

[akhudzu ma uhibbu walakinna la astathi'u an a'milihi]

'saya ambil yang saya suka, tetapi saya tidak bisa melakukannya'

Ditinjau dari pemakaian kaidah bahasa Arab, أن (an) yang terletak di akhir kalimat contoh di atas disebut charf nashb atau letters of opening (Dahdah, 1992:17-18). Charf ini mempunyai pengaruh (kasus) terhadap verba sesudahnya menjadi a'mila, yaitu menjadi kasus causative atau berbunyi a pada akhir verbanya. Akan tetapi, pada kenyataannya dalam contoh kalimat tersebut si pembelajar membuat kesalahan dan mejadikan verbanya berbunyi $i$ (a'mili) atau berkasus genitif.

Distorsi semacam itulah yang sering dilakukan oleh dwibahasawan, dalam hal ini mahasiwa. Hal itu berhubungan erat dengan perbedaanperbedaan aturan atau kaidah yang terdapat pada bahasa ibunya dan bahasa yang sedang dipelajari. Dari itulah maka permasalahan yang muncul adalah pada tataran sintaksis yang mana sajakah kesalahan-kesalahan itu dilakukan oleh pembelajar yang sedang mempelajari bahasa Arab ini sebagai bahasa keduanya.

Tujuan penelitian ini adalah untuk mendapat gambaran tentang bagaimana penerapan gramatika bahasa Arab oleh mahasiswa Sastra Arab dalam membaca teks ataupun menulis teks bahasa Arab yang dihadapi. Hasil penelitian ini diharapkan juga dapat memberikan pemahaman yang tepat dan metode pembelajaran yang sesuai dengan kondisi yang dimiliki oleh mahasiswa.

Penelitian ini mendasarkan analisisnya pada teori sintaksis bagasa 
Arab. Bahasa adalah sebuah sistem. Sebagai sebuah sistem, bahasa itu sekaligus bersifat sistematis dan sistemis. Bahasa bersifat sistematis karena bahasa tersusun menurut pola tertentu (berkaidah), tidak tersusun secara acak. Bersifat sistemis, bahasa bukan merupakan sistem tunggal, tetapi terdiri atas sejumlah subsistem: fonologi, morfologi, sintaksis, dan semantik, maka bahasa juga bersifat unik dan universal (Chaer, 2007:33-35). Dalam bahasa Arab aturan pola-pola atau kaidah bahasa Arab tersebut dikatakan oleh Dahdah (1992:2) sebagai

$$
\begin{aligned}
& \text { "علم تعرف به أحوال الكلمات مفردة }
\end{aligned}
$$

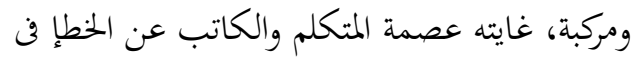

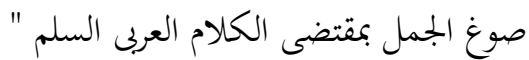

Kaidah (garamatika) bahasa Arab adalah ilmu yang mempelajari tentang ihwal kata-kata, baik yang mandiri ataupun yang tersusun. Tujuannya adalah untuk menjaga pembicara atau penulis dari kesalahan penyusunan dalam kalimat bahasa Arab yang baik dan benar.

Aturan-aturan tersebut dibahas dalam sintaksis. Sebagaimana juga hal tersebut dikatakan oleh Wijana (2011:77) bahwa sintaksis merupakan cabang linguistik yang mempelajari perihal penggabungan atau penataan satuansatuan lingual yang berupa kata untuk membentuk satuan yang lebih besar seperti frasa, klausa, dan kalimat. Verhaar (2004:161) juga mengatakan bahwa masalah struktur sintaksis, mencakup masalah fungsi, kategori, dan peran termasuk dalam pembahasan sintaksis. Adapun kaidah bahasa atau sistem kaidah bahasa Arab adalah sebagai standar acuan atau kriteria yang digunakan untuk menentukan suatu bentuk tuturan yang ada salah atau tidak menurut sistem kaidah bahasa Arab baku.

Data penelitian ini dikumpulkan dari naskah hasil ujian Telah Teks Arab I dan III mahasiswa Prodi Sastra Arab. Naskah atau teks ujian yang digunakan sebagai data ini sudah tidak menggunakan tanda baca lagi atau sudah dihilangkan tanda bacanya. Dengan menggunakan metode simak, semua data yang dikumpulkan kemudian diklasifikasikan secara saksama menurut tipe-tipenya. Selanjutnya, data yang sudah dikalasifikasikan kemudian dianalisis dan membandingkannya dengan kaidahkaidah yang digunakan dalam sintaksis bahasa Arab.

Prosedur analisis kesalahan berbahasa terdiri atas tiga langkah yang saling berkaitan, yaitu identifikasi, deskripsi, dan penjelasan. Dengan demikian, bentuk-bentuk kesalahan yang terjadi tersebut akan lebih tepat dikaji dan dideskripsikan dengan memanfaatkan teori atau kaidah-kaidah bahasa Arab.

Kesalahan-kesalahan yang dilakukan oleh mahasiwa ketika mengerjakan soal-soal ujian ini dikelompokkan menjadi dua kelompok, yaitu kelompok semester 1 dan kelompok semester III. Kesalahan-kesalahan tersebut masing-masing akan ditunjukkan dan dianalisis, baik dari kesalahan tataran leksikal, frasa, maupun klausanya.

\section{PEMBAHASAN}

\section{Kelompok Semester 1}

\section{A. Leksikal}

Kesalahan yang terjadi pada tataran ini ketika pembelajar mendapatkan katakata yang berfonem akhir alif. Misalanya:

$$
\text { 1. هو يذهب الم عمله صباحا }
$$

Huwa yazhabu ilā 'amalihī shabāhan 'Dia pergi bekerja di pagi hari'

2. ويعود الى بيته مساء

Wa ya 'udu ilā baitih̄̄ masā'an 'Dia pulang (kerja) sore hari'

3. يعمل في شَرَكَةِ الطيران

ya'malufi syarukatith-thairāni

'(Umar) bekerja di perusahaan penerbangan'

4. كانت القبائل تَظنّ 
kānat al-qabā'ilu tazhanna

'Kabilah itu menyangka ...'

$$
\text { 5. فشْكُر الله }
$$

'Maka dia bersyukur kepada Allah'

Katashabāchan dan masā'an dalam kalimat (1) dan (2) di atas merupakan keterangan waktu. Keterangan waktu ini di dalam bahasa Arab dikategorikan sebagai objek atau maf'ūl fìh. Sebagai objek, kata tersebut wajib manshūb (accusative). Tanda yang dilekatkan pada kata tersebut adalah berbunyi $a$ pada akhir kata. Oleh karena kata shabāchan berbentuk nakirah atau tak tentu, maka kata tersebut dibaca tanwin shabāchandan mas $\bar{a}$ 'andengan ada tambahan fonem alif di akhir kata sehingga berbunyi $\underline{a n}$.

Dalam kenyataannya pembelajar memberikan tanda bunyi akhir pada kata tersebut dengan penanda $\underline{u}$ sehingga kata tersebut menjadishabāhudan masā'u. Dalam gramatika bahasa Arab, penyertaan fonem alif di akhir kata untuk menandai bahwa kata tersebut adalah kata tak tentu (nakirah) dan tanda panjang ( $\mathrm{mad}$ ). Katakata tersebut selamanya akan dibaca $a$ atau an dan tidak akan dibaca selain itu. $\mathrm{Hal}$ ini mengingat kedudukan atau fungsi kata tersebut adalah sebagai objek yang berupa keterangan zharaf atau maf' $\bar{u} l$ fih 'circumstantial patien' (Dahdah, 1992:171).

Kata شركة syirkati 'perusahaan' pada contoh kalimat (3) adalah kata yang sudah menjadi bahasa Indonesia, yaitu kata 'serikat' yang berarti 'perkumpulan persekutuan dangang, perseroan, kongsi' (KBBI, 2013:788). Kata tersebut oleh pembelajar diberi penanda yang bermacam-macam, yaitu syarikati, syarakat, dan syarukati. Pada contoh ini, pembelajar sudah ingat bahwa kata syirkah adalah bentuk genetif karena didahului oleh ccharf atau partikel fi (preposisi), maka kata tersebut harus ditandai dengan $i$. Akan tetapi, mereka ragu-ragu dalam menentukan apakah penanda yang tepat pada kata ini sehingga memberikan penanda berbeda-beda. Verba mudhari (akan datang/sedang datang) 'menyangka atau mengira' (Munawir, 1997:883) pada kalimat contoh (4) adalah verba yang berasal dari bentuk madhy 'lampau' menjadi تَظَنُّن (diawali dengan ta) karena kata benda yang menjadi subjeknya adalah bentuk muannats 'feminin'.Dalam kenyataannya verba ini oleh pembelajar diberi penanda tazhanni dan tuzhanni yang tidak ditemukan dalam kaidah fonologi bahasa Arab. Pada dasarnya kata ini juga sudah sering didengar oleh umum di Indonesia dengan kata su'uzhan atau 'buruk sangka'. Akan tetapi, pembelajar tampaknya belum mengenal betul asli kata tersebut dalam bahasa Arab, maka mereka mengira verba tersebut adalah berasal dari verba zhanni. Padahal verba tersebut berasal dari zhanna-yazhannu bukan berasal dari zhanna-yazhinnu.

$$
\text { Verba syakara شَكَ 'bersyukur' pada }
$$
contoh kalimat (4) memiliki kedekatan bunyi atau suara dengan kalimat usykurullāha 'bersyukurlah kepada Allah'. Verba bentuk lampau ini memang memiliki verba imperative usykur أَشْكُرْ 'bersyukurlah'. Kesalahan pembelajar terjadi karena menyamakan bentuk imperatif verba tersebut dengan bentuk verba madhinya, maka langsung memberi penanda yang akhirnya menjadi seperti pada kalimat contoh kalimat (4) tersebut. Padahal kalimat tersebut semestinya diberi penanda baca fasyakarallāha 'maka dia bersyukur kepada Allah'.

\section{B. Frasa}

Selain bentuk leksikal di atas, dalam pekerjaannya pembelajar juga selalu mengalami kebingungan memberikan penanda pada jenis frasa preposisional (Ramlan, 2000:163). Misalnya:

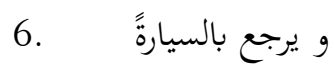


Wa yarji $u$ bissayyārati 'Dia pulang dengan (naik) bis'

7. ilal math 'ami lil 'asyā'i

'(pergi) ke rumah makan untuk makan malam ...'

8.

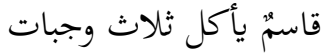

Qāsimun ya'kulu tsalātsa wajabātin

'Qasim makan tiga kali (sehari)'

9.

$$
\begin{aligned}
& \text { سمير يأكل وجبةٍ واحدةٍ } \\
& \text { Wajbatan wāhidatan } \\
& \text { 'sekali makan' }
\end{aligned}
$$

Frasa bis sayyārati 'dengan bis' pada contoh (6) dan lil 'asyā'i pada contoh (7) di atas merupakan susunan dua kata yang dikategorikan sebagai frase preposisional (jar majrūr). Jar-majrūr (JM) ialah susunan dua konstituen yang terdiri dari charf jar 'preposisi' bi 'dengan' dan diikuti konstituen lain yang bertindak sebagai majrūr (genitif). Konstituen yang berupa charf jar atau partikel dalam konstruksi ini dapat disejajarkan dengan unsur perangkai dan konstituen yang disebut majrūr dapat disejajarkan dengan unsur sumbu (Masrukhi, 2003:79). Dalam frasa ini, unsur perangkai atau partikel memiliki pengaruh terhadap unsur sumbu yang harus diikuti, yaitu berpenanda $i$ pada akhir katanya. Akan tetapi, sebagaimana diketahui bahwa pembelajar membuat kesalahan ketika menjawab soal, yaitu ada yang diberikan penanda $a$ dan an seperti contoh (3) dan (4) di atas da nada pula yang memberikan penada dengan in dan in pada akhir kata وجبةٍ واحدة.

Begitu pula frasa preposisional pada contoh (7) terdiri atas preposisi $l i$ 'untuk' diikuti konstituen lain sebagai majrūrnya juga terjadi kesalahan oleh pembelajar dalam menentukan penandanya. Kata eشlecara tekstual sama dengan zharaf (menunjukkan waktu), yaitu waktu 'isya'. Di sini pembelajar mengalami kesulitan menentukan kata tersebut diberi penanda bagaimana mestinya sehingga yang terjadi adalah kata tersebut diberi penanda lil 'asyā'a, lil 'isyā'a, lil 'isyā'i, dan lil isy $\bar{a}$ 'u. Dalam hal ini pembelajar kurang memperhatikan susunan frasa perposisional yang dimaksud. Maka terjadilah kesalahan menentukan penanda yang tepat sesuai dengan kaidah garmatikal bahasa Arab yang berlaku.

Pada kalimat contoh (8) terdapat dua kata tsalātsawajabātin 'tiga (kali) makan' yang digabung yang tidak predikatif. Dalam bahasa Arab konstruksi semacam itu disebut sebagai frasa 'adady (Asrori, 2004:57) atau frasa numeral (Masrukhi, 2003:63), yaitu satuan gramatikal yang keseluruhan distribusinya dapat digantikan oleh konstituen yang berupa numeralia sebagai intinya dan konstituen yang lain menjadi pewatasnya. Asrori (2004:57) menyebutkan bahwa frasa adady ini unsur-unsurnya tidak begitu saja dapat diubah urutannya atau disisipi dengan unsur yang lain. Adapun penanda yang dilekatkan pada unsur-unsur atau masing-masing konstituen ini adalah konstituen inti atau numeralnya sesuai posisi atau kedudukannya dalam kalimat, sedangkan pewatasnya adalah genitif (Rajihi, 2016:396).

Bentuk tulisan وجباتmirip dengan yang umum diketahui pembelajar, yaitu kata وجب Oleh karena itu, di dalam lembar jawaban ujian pembelajar memberi penanda kata tersebut bermacam-macam, yaitu:

$$
\begin{aligned}
& \text { ثانلا ثُجِباتِ } \\
& \text { ثان أُ وِجباتُ } \\
& \text { tsalatsa wajibatin }
\end{aligned}
$$

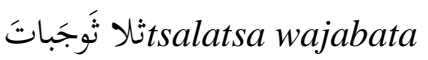

Dari bermacam-macamnya pemberian penanda ini dapat disimpulkan bahwa pembelajar belum tahu atau belum paham posisi dan bagaimana penanda yang harus dilekatkan pada masingmasing unsur frasa numeral tersebut. 
Dengan demikian frasa di atas penandanya adalah tsalatsawajbatin.

Adapun contoh frasa (9) disebut sebagai frasa adjectiva atau murakkab washfi (MW). Yang dimaksud MW ialah satuan gramatikal yang tersusun atas dua nomina. Nomina pertama wajbatan 'makan' disebut maushüf 'yang disifati' (inti), sedangkan nomina kedua (modifikator) atau menerangkan keadaan maushüf atau keadaan yang melekat padanya, yaitu wachidatan '(hanya) sekali'. Unsur kedua MW selalu berupa ism shifat 'kata sifat' atau adjektiva. Karena itu, konstruksi tersebut disebut murakkab washfi 'konstruksi adjektival' (Masrukhi, 2003:74).

\section{Kalimat}

Kesalahan berikutnya adalah kesalahan pembelajar dalam menentukan penanda yang harus dilakukan pada kalimat bahasa Arab. Penanda-penanda tersebut pada dasaranya adalah untuk menentukan bahwa kata yang bersangkutan menempati posisi tertentu dalam kalimat tersebut. Misalnya,

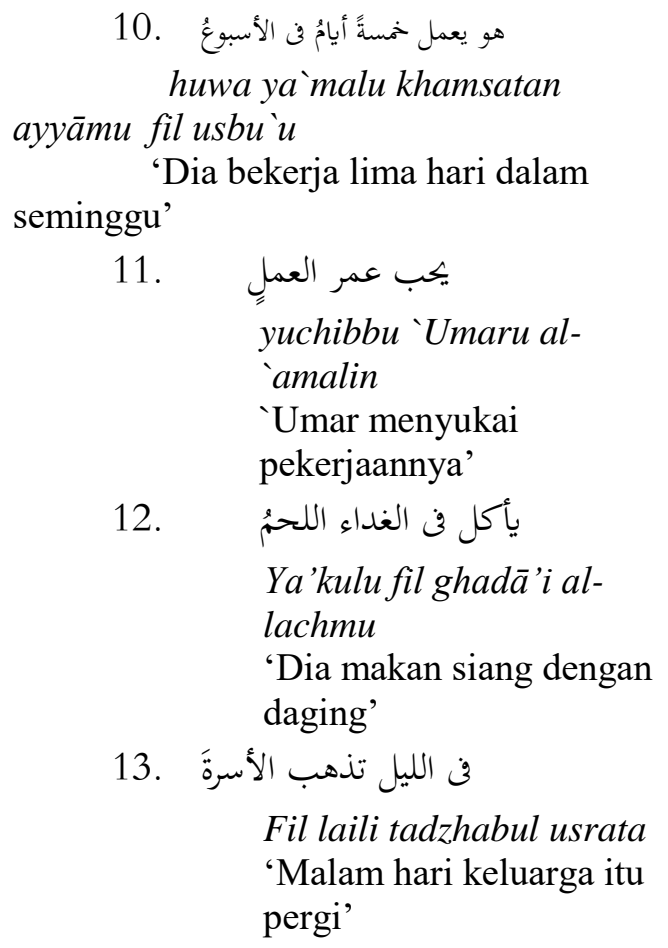

10. هو يعمل خمسةً أيامُ فن الأسبوعُ
Dua katakhamsatan ayyāmu pada kalimat contoh (10) di atas merupakan konstruksi frasa ‘adady (numeral) sebagaimana pada contoh (8) di atas. Dalam bahasa Arab yang disebut murakkab 'adadī. Frasa ini ada dua macam, pertama konstruksi yang berkaitan dengan 'konstruksi majemuk' dan 'konstruksi numeral'. Yang berkaitan dengan konstruksi majemuk ialah konstruksi dua numeralia yang di antara keduanya diperkirakan terdapat kata hubung waw 'athaf 'dan'. Dan kedua adalah konstruksi yang terdiri dari numeralia sebagai konstituen pertama disebut 'adad 'penghitung' dan konstituen lain berupa nomina disebut $m a$ ' $d \bar{u} d$ 'yang dihitung' (Masrukhi, 2002:77-78) sebagaimana contoh di atas. Ketentuan konstruksi ‘adad 'penghitung' adalah mengikuti kedudukan konstituen tersebut dalam kalimat dan konstituen lain berupa nomina disebut $m a$ 'dūd 'yang dihitung' bertanda genitif atau bunyi $i$.

Jika diperhatikan kalimat di atas kedudukan frasa khamsatan ayyāmu adalah sebagai objek, maka akhir kata khamsatan seharusnya ditandai dengan kausatif $a$ saja tidak dengan penanda tanwin an. Penanda tanwin yang diberikan pembelajar pada numeral tersebut mungkin dianggapnya sebagai kata yang tidak berawalan alif lam, makadianggapnya sebagai kata yang tak tentu (nakirah), sedangkan nomina ауyа̄mu 'yang dihitung' ditandai dengan genitif atau $i$. Sementara yang terjadi pembelajar justru melakukan kesalahan, baik pada ‘adad maupun ma`dudnya, yaitu khamsatan ayyāmu yang seharusnya dibaca khamsata ayyamin'lima hari'.

\section{Kelompok Semester III}

Sebagaimana pada kelompok Semseter I di atas, teks ujian pada kelompok Semester III ini memang sudah sejak kuliah tidak bertanda baca atau dihilangkan tanda bacanya. Adapun kesalahan-kesalahan yang terjadi pada pembelajar pada semester yang lebih 
tinggi ini, hasil yang diperoleh dalam penelitian ini adalah sebagai berikut.

\section{A. Leksikon}

Kesalahan yang terjadi pada tataran leksikon ini pembelajar masih belum fokus pada leksikon, baik nomina maupun verba. Hal tersebut dapat diberikan contoh hasil tulisan berikut:

14

$$
\text { يكمَل حقيبته }
$$

yachmalu chaqībatihī

'Dia membawa kopornya'

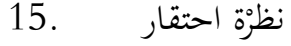

$$
\begin{aligned}
& \text { nazhartu ichtiqārin } \\
& \text { 'Pandangan yang melecehkan' } \\
& \text { 16. ويأخِذُه النَّكورَ } \\
& \text { wa ya' khidzuhū adz-dzakūra } \\
& \text { 'dan (hanya) mengambil anak } \\
& \text { laki-laki' }
\end{aligned}
$$

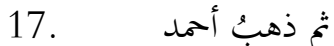

$$
\begin{aligned}
& \text { tsumma dzahabu achmadu } \\
& \text { 'Kemudian pergilah Ahmad' }
\end{aligned}
$$

Dari kelompok semsester III ini ada beberapa hal yang menarik, yaitu pembelajar yang sudah lebih tinggi tingkatannya dari yang sebelumnya masih mengalami kesalahan-kesalahan yang tidak seharusnya terjadi. Misalnya, pemakaian verba yachmalu pada contoh (14) di atas tidak ditemukan dalam bahasa Arab. Yang ada adalah verba chamalayachmilu'membawa, memikul' (Munawir, 1997:297). Kesalahan semacam ini mestinya tidak perlu terjadi apabila pembelajar memperhatikan perubahan bentuk verba dari bentuk lampau madhi menjadi bentuk kini atau akan datang mudhari`. Dengan demikian verba pada kalimat tersebut mestinya adalah yachmilu chaqibatahu 'Dia membawa kopornya'.

Demikian juga contoh berikutnya (15), yaitu kata nazhartu. Kata tersebut sebetulnya bukan verba melainkan nomina nazhrah 'pandangan', sedangkan apabila dibaca nazhartu adalah verba 'saya melihat'. Akan tetapi, pembelajar lupa bahwa bentuk huruf terakhir pada nomina adalah $t a$ ' marbuthah (:) 'penanda jenis perempuan'bukan $t a$ ' dlamir 'kata ganti atau pronomina persona'. Namun, nomina tersebut berasal

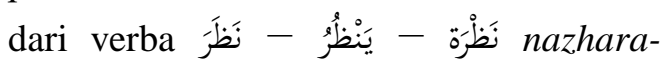
yanzhuru-nazhrah.

Verba ya'khidzu pada contoh (16) dan dzahabu pada contoh (17) adalah verba yang sudah sering digunakan dalam berbagai kalimat bahasa Arab. Akan tetapi, pembelajar masih mengalami kesalahan dalam pelaksanaan dan praktiknya. Verba ya'khidzu tidak ditemukan, tetapi pembelajar yakin bahwa verba itu berasal dari verba lampau akhadza 'mengambil'. Verba ini, bentuk mudlari'nya mengikuti wazan yaf ulu bukan yafilu, seperti jalasa-yajlisu sehingga verba tersebut mestinya dibaca dan ditulis ya'khudzu 'mengambil' (Munawir, 1997:11).

Sementara verba dzahabu, yang teringat oleh pembelajar adalah penanda akhir pada bentuk mudhari'nya, yaitu yadzhabu. Verba madhi selalu berpenanda $a$ pada kahir katanya sehingga tidak ada verba madhi yang penanda akhirnya berbunyi $u$, seperti $d z a h a b u$.

\section{B. Frasa}

Dalam bahasa Arab terdapat dua bentuk frasa yang sudah umum digunakan, yaitu frasa idhāfi dan frasa washfi. Frasa idhāfì (FI) ialah dihubungkannya (nisbat) dua kata atau lebih dan tidak melebihi batas fungsi (Ramlan, 1981:23). Kata yang pertama disebut mudhāf 'sandaran' (governing word), dan yang kedua disebut mudhäf 'ilaih 'yang bersandar'. Mudhāf 'ilaih dapat berupa kata yang ma 'rifat 'tertentu' (ber-al) atau yang nakirah 'tak tentu'. Di samping itu, mudhāf 'ilaih harus majrūr 'genitif' karena di antara dua kata tersebut terdapat harf jar atau partikel yang tersembunyi (Masrukhi, 2003:66) (lihat juga al-Ghulayaini, 1980, I:15, III:205, 
Nadwi, 1990:44, al-Hasyimy, 1410:181183, Thatcher, 1958:42).

FI adalah suatu konstruksi yang digunakan untuk menyatakan makna posesif atau milik. Artinya, nomina pertama atau mudhāf sebagaikonstituen termilik dan nomina kedua atau mudlaf 'ilaih sebagai pemiliknya. Jika dilihat unsur-unsur pengisinya, FI dapat diisi oleh nomina+nomina serta nomina+ (nomina+pronomina). Dilihat dari partikel-partikel yang tersembunyi dalam frasa ini diperkirakan di antara konstruksi tersebut terdapat partikel $l i$ 'milik' disebut idhafah lamiyah (posesif).

Sementara frasa washfi atau frasa adjektiva sebagaimana yang disebutkan di atas adalah satuan gramatikal yang tersusun atas dua nomina. Nomina pertama disebut maushūf 'yang disifati' (inti), sedangkan nomina kedua (modifikator) atau menerangkan keadaan maushüf atau keadaan yang melekat padanya. Unsur kedua frasa ini selalu berupa isim shifat 'kata sifat' atau adjektiva. Penanda yang dilekatkan pada frasa ini tergantung posisi frasa tersebut dalam kalimat, baik sebagai subjek, predikat maupun objek. Di samping itu, penanda pada kedua unsur ini selalu sama, baik tunggal, ganda, maupun jamaknya, demikian pula jenis maskulin maupun femininnya.

Kesalahan pemahaman dan kesalahan pemakaian para pembelajar terjadi pada konstruksi frasa adjektiva. Adapun hasil yang diperoleh dari jawaban pembelajar dapat ditunjukkan pada contoh-contoh sebagai berikut.

$$
\begin{aligned}
& \text { 18. حقيبته يحمَل } \\
& \text { yachmalu chaqībatihi }
\end{aligned}
$$

'Dia membawa kopornya'

19.

$$
\text { ببعضَهم إلى وأدُ البنات }
$$

biba 'dhahumilā wa'dul banāt 'sebagian mereka sampai(tega) membunuh anak2 perempuan'

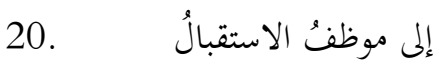

$$
\begin{aligned}
& \text { ilā muwazhzhafu al-istiqbālu } \\
& \text { 'kepada petugas penerima } \\
& \text { tamu (hotel)' } \\
& \text { 21. لمدة أسبوع واحد } \\
& \text { Limuddati usbūi wachidi } \\
& \text { 'kira-kira satu minggu' } \\
& \text { 22. كانت المرأةٌ العربية }
\end{aligned}
$$

Kānat al-mar'atu al-'arabiyyati 'Konon wanita Arab...'

Konstruksi chaqībatihi 'kopornya' pada contoh (18), wa'dil banāt 'membunuh anak-anak perempuannya' pada contoh kalimat (19), dan muwazhzhafil istiqbāl 'pegawai penerima tamu (hotel)' atau 'resepsionis', pada contoh (20) merupakan gabungan dua kata yang masuk kategori frasa idhāfi. Artinya, gabungan dua kata tersebut memiliki makna posesif. Kata yang diberi beban sebagai termilik mudhāf sesuai dengan kedudukannya dalam kalimat atau didahului oleh kata tugas (preposisi), seperti ila, min, li, dan sebaginya. Oleh karena itu kata (termilik) harus mengikuti ketentuan ini, maka kata yang menjadi modifikatornya harus selalu genitif. Misalnya, frasa chaqībatihi pada contoh (18) terdiri atas chaqībatun+hi. Jika dilihat dari kedudukan masing-masing kata tersebut dalam kalimat nomina chaqībah 'kopor' berkedudukan sebagai maf ül bih atau objek dari verba yachmilu 'Dia membawa'.

Objek atau maf "ūl dalam bahasa Arab selalu bertanda manshūb atau akusatif. Oleh karena itu, nomina tersebut seharusnya dibaca chaqībata, sedangkan pronomina $h u$ adalah sebagai pemiliknya (Dia). Sementara pronomina $h u$ akan menyesuaikan dengan kondisi nomina termilik. Dia akan ditandai dengan $h u$ apabila nimona pemilik berpenanda $m a n s h \bar{u} b$ dan akan ditandai dengan $h i$ apabila nomina pemilik adalah genitif.

Demikain pula dengan frasa wa'dul banāti pada contoh (19) dan frasa 
muwazhzhafil istiqbāli pada contoh (20). Konstruksi frasa tersebut sebelumnya didahului oleh partikel atau kata tugas (preposisi) ilā, maka nomina wa'dun semestinya berpenanda majrūr atau $i$ dan bukan $w a^{\prime} d u$ lagi. Begitu juga dengan muwazhzhafi pada contoh (20) menurut kaidah gramatika bahasa Arab semestinya berpenanda $i$. Sementara nomina keduanya sebagai pemiliknya juga berpenanda majrūr atau $i$ menjadi albanāti dan al-istiqbāli.

Berikutnya adalah konstruksi frasa washfi atau frasa adjektiva. Kesalahankesalahan penulisan dan pemahaman oleh pembelajar yang terjadi dapat ditunjukkan pada contoh-contoh (21) dan (22). Pada contoh tersebut frasa adjektiva yang disebutkan adalah usbu $i$ wāchidi (21) dan al-mar'atu al-'arabiyyatu (22).

Dalam kaidah bahasa Arab bentuk kata ada dua macam, yaitu kata yang ma`rifat (tertentu) dan kata yang nakirah (tak tentu). Penanda kedua macam kata tersebut adalah ada atau tidak adanya tanda al pada kata itu. Kata yang dilekati penanda al berarti ma'rifat dan yang tidak dilekati berarti nakirah. Kata yang berpenanda al, maka kata tersebut harus dibaca tak tanwin, seperti al-'arabiyyatu, al-lachmu, dan sebagainya, sedangkan kata yang nakirah (tak tentu) pasti tidak ada penanda al pada kata tersebut. Penanda kata tersebut menyesuaikan kedudukannya dalam kalimat dan harus dibaca dengan tanwin, seperti kalimatun, majlisun, dan seterusnya. Tanda baca yang digunakan dalam frasa adjektiva ini adalah kata yang pertama atau yang disifati, maka penandanya menyesuaikan dengan kedudukannya dalam kalimat, sedangkan kata yang kedua atau sifatnya adalah menyusaikan dengan kata yang pertama atau yang disifati.

Dari keterangan tersebut, maka contoh-contoh di atas dapat dijelaskan kesalahannya adalah kata usbūi $i$ wāchidi (21) adalah jenis kata yang nakirah atau tidak ber-al, maka harus tanwin. Konstruksi kata-kata tersebut terletak di belakang konstruksi yang dilekati preposisi, maka akan diberi penanda majrūr atau $i$. Dengan demikian kenstruksi tersebut harus diberi penanda majrūr dan tanwin dan dibaca usbūin wāhidin.

Sebaliknya, pada contoh (22) konstruksi yang disebut frasa adjektiva adalah al-mar'atu al-'arabiyyatu. Jika diperhatikan kedua nomina tersebut, masing-masing ber-al dan memiliki ciriciri yang sama, maka dapat dipastikan konstruksi gabungan dua nomina tersebut adalah frasa adjektiva. Kāna adalah verba yang memiliki pengaruh, yaitu nomina yang berada setelahnya disebut sebagai nominanya atau ismnya. Penanda yang melekat pada nomin'a tersebut harus nominatif atau marfü $`$. Oleh karena, kedua nomina tersebut diyakini sebagai konstruksi frasa adjektiva, maka keduanya harus bertanda baca sama, yaitu almar'tu al-'arabiyyatu bukan al-mar'atu al-`arabiyyati.

\section{Kalimat}

Kalimat dalam bahasa Arab disebut al-jumlah, yaitu ada al-jumlah al-ismiyah atau kalimat nominal dan al-jumlatuh alfi liyah atau kalimat verbal. Al-jumlah alismiyah terdiri atas mubtada' (subjek) dan khabar (predikat), sedangkan al-jumlah al-fi liyah terdiri atas $f i\urcorner$ (verba) dan $f a ̄ i l$ (pelaku).

Kesalahan yang terjadi pada konstruksi kalimat bahasa Arab oleh pembelajar dalam penelitian ini dapat ditunjukkan pada contoh-contoh berikut.

$$
\begin{aligned}
& \text { 23. كانت المرأةٌ العربيةِ في العصر الجاهلية } \\
& \text { محرومةُ } \\
& \text { kānat al-mar'atul } \\
& \text { 'arabiyyati fil 'ashril } \\
& \text { jāhiliyyati machrumatu } \\
& \text { 'Perempuan Arab pada } \\
& \text { masa Jahiliyah tertindas' } \\
& \text { 24. بعض القبائلَ تحرم المرأةِ } \\
& \text { ba`dhul qabāila tuchrimul } \\
& \text { mar'ati }
\end{aligned}
$$


'sebagian suku menghilangkan (hak) perempuan'

25.

$$
\text { وأعطاه بعضَ النقودَ }
$$

wa a 'thāhu ba'dhan nuqūda

'dan memberinya uang (lelah)'

Sebagaimana dijelaskan di depan bahwa kāna memiliki pengaruh terhadap konstituen-konstituen yang berada di belakangnya, yaitu ada ism kāna dan ada khabar kāna. Ketentuan yang berlaku pada kedua kata tersebut adalah: yang pertama, isim 'kāna dan khabar kāna keduanya harus diberi tanda kasus nominative atau marfü . Kedua, ism kāna harus ma'rifat dan khabar kāna harus nakirah. Contoh ketentuan tersebut dapat diperhatikan pada contoh sebelumnya.

Nomina al-mar'atu al-`arabiyyatu berkedudukan sebagai ism kāna. Tanda nominatifnya tempak jelas pada bunyi akhir katanya, yaitu bunyi $u$, sedangkan mucharramatun merupakan khabar kāna, tanda nominatifnya adalah berupa tanwin un pada bunyi akhir katanya. Dengan demikian kesalahan yang terjadi pada pembelajar adalah memberikan tanda baca al-mar'atul 'arabiyyati dan machrumatu yang seharusnya adalah diberi penanda nominatif pada akhir katanya dengan tanda $u$ pada ism kāna dan un pada khabar kānanya al-mar'atu al-'arabiyyatu fi al‘ashri al-jāhiliyyati mucharrumatun.

Pada contoh berikutnya merupakan konstruksi kalimat atau aljumlah al-ismiyah atau kalimat nominal. Dua kata yang pertama ba'dhul qabāila adalah frase $i d h \bar{a} f \hat{\imath}$ yang di dalam kalimat tersebut berkedudukan sebagai subjek kalimat. Sebagaimana dijelaskan di depan bahwa susunan tersebut memiliki makna posesif yang terdiri atas termilik mudhāf dan pemilik mudhāf ilaih. Konstituen pemilik harus berpenanda kasus genetif, maka dia harus berbunyi $i$ bukan seperti yang ada pada jawaban pembelajar pada contoh di atas, yaitu berbunyi al-qabāila.
Konstruksi tersebut mestinya berbunyi ba'dhu al-qābaili 'sebagian kabilah'.

Sementara predikat kalimat nominal tersebut berupa kalimat verbal atau aljumlah al-fi liyah, yaitu konstruksi tuchrimul mar'ati 'yang terdiri atas verba, pelaku, dan objek. Verba tuchrimu dalam bahasa Arab tidak ditemukan. Yang ada adalah tachrumu 'mencabut hak warisnya' (Munawir, 1997:256). Pelaku dalam kalimat ini adalah pronomina orang ketiga perempuan yang merujuk kepada al-qabāili (jamak dari mufrad qabilatun). Nomina yang terakhir adalah al-mar'ati 'perempuan'. Nomina tersebut dalam kalimat sebenarnya berkedudukan sebagai objek kalimat, yaitu 'Sebagian suku (Arab Jahili) mencabut hak waris perempuan'. Sebagai objek atau maf'ūl bih ketentuan dalam bahasa Arab adalah berpenanda kasus akusatif atau manshūb . Tanda yang dilekatkan pada nomina tersebut semestinya adalah $a$ bukan $i$ sebagaimana yang tertera di dalam hasil jawaban pembelajar, yaitu al-mar'ati.

Sebaliknya, pada contoh terakhir (25) kalimat wa a'thāhu ba'dha an- nuqūda juga konstruksi kalimat verbal yang terdiri

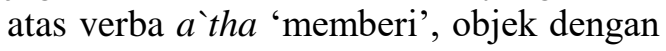
pronomina $h u$ 'dia (laki-laki)', dan objek kedua $b a^{\prime} d h u$ an-nuqūdi 'sedikit uang'. Akan tetapi, pembelajar mengalami kerancuan pemahaman atau salah menempatkan penanda-penanda yang tepat sesuai dengan kedudukan kata-kata tersebut di dalam kalimat. Maka dari itu pembelajar memberikan penanda pada posisi atau kedudukan pada masingmasing kata tersebut seperti pada contoh kalimat (25) di atas. Kesalahan memberi penanda kedudukan pada kata tersebut mengakibatkan arti kalimat tersebut menjadi jauh dari pengertian yang sebenarnya, yaitu wa a'thahu ba'dha annuquda 'Dia memberinya (portir) kepada tip'. Pengertian ini sama sekali tidak mungkin akan terjadi, yaitu orang diberikan kepada sesuatu yang tidak berujud dan tidak berakal. Padahal yang dimaksudkan dalam teks aslinya adalah 'Dia memberinya (portir) tip'. 


\section{KESIMPULAN}

Bahasa Arab merupakan bahasa kedua atau ketiga bagi mahasiswa Sastra Arab. Kaidah bahasa kedua ini berbeda dengan bahasa yang lainnya. Penguasaan kaidah bahasa kedua inipun berbeda antara yang satu dengan yang lainnya. Kurang terkuasainya aturan atau kaidah bahasa baru oleh sebagian pembelajar ini kemudian mengakibatkan kurang cermat dan salah dalam mengaplikasikannya.

Dari penelitian ini kesalahan yang terjadi ditemukan di bebagai tataran sintaksis, yaitu pada tataran leksikon, frasa $i d h \bar{a} f \bar{\imath}$ dan frasa washfi, dan pada klausanya. Pada tataran leksikon antara lain belum terkuasainya bentuk-bentuk konjugasi verba. Pada tataran frasa dan klausa masih ada kesulitan bagi pembelajar memahami fungsi unsur-unsur sintaksis berikut penandanya, seperti penanda fungsi mudhāf, mudhāf ilaih, maf" $\bar{l}$ bih, dan sebagainya.

\section{Daftar Pustaka}

Abdul Massih, George. M. 1999. Mu'jamul I'rab fi An-Nahwi Al'Arabiy: Qawa'id wa Tathbiqat wa Fihrisat. Libanon: Matba'ah Lubnan Nasyirun.

Asrori, Imam.2004. Sintaksis Bahasa Arab. Malang: Penerbit Misykat.

Borsley, Robert. D. 1992. Syntactic Theory A Unified Approach. London: Edward Arnold.

Dahdah, Antoine. 1992. Universal Arabic Grammar. Lebanon: Librairie du Liban.

Al-Ghulayainiy. Musthafa. 2005. Jami'ud Durus Al-'Arabiyah.Kairo: Dar Al-Hadits.

Kesuma, Tri Mastoyo Jati, 2007. Pengantar (Metode) Penelitian Bahasa. Yogyakarta: Carasvatibooks.
Masrukhi, Moh. 2003. 'Pengaruh Konstruksi Frasa Bahasa Arab pada Konstruksi Frasa Bahasa Jawa pada Kitab-Kitab Klasik. Yogyakarta: Thesis Sekolah Pascasarjana Universitas Gadjah Mada.

Munawar, Ahmad Warson. 1997. Kamus Al-Munawwir Arab-Indonesia Telengkap. Yogyakarta: Pustaka Progressif.

Pateda. Mansoer. 1989. Analisis Kesalahan. Cetakan I. Flores: Penerbit Nusa Indah.

Rajihi, Abduh. 2016. At-Tathbiqu AnNahwiy.Riyadh: Maktabah AlMa'arif Li An-Nasyr wa AtTauzi`.

Ramlan, M. 1981. Sintaksis. Yogyakarta, CV. Karyono.

Sudaryanto, 1993. Metode dan Teknik Analisis Bahasa Pengantar Penelitian Wahana Kebudayaan Secara Linguistis. Yogyakarta: Duta Wacana University Press.

Supardi. 2016. 'Tipe-tipe Kesalahan Konkordansi Gramatikal Bahasa Arab: Studi Kasus pada Karangan Pembelajar IAIN Salatiga 20132014. Yogyakarta: Disertasi Sekolah Pascasarjana UGM. 